\title{
EVALUATION OF CARDIAC FUNCTION IN DIABETES MELLITUS
}

\author{
Mridulkumar Kannath ${ }^{1}$
}

${ }_{1}^{1}$ Associate Professor, Department of General Medicine, Government Medical College, Kozhikode, Kerala, India.

\section{ABSTRACT}

\section{BACKGROUND}

Diabetes mellitus is associated with long-term organ complications, microvascular and macrovascular. It is associated with cardiovascular disease, which is correlated to microalbuminuria and proteinuria. Diabetes is a risk factor for coronary artery disease and congestive heart failure. The present study is aimed to assess cardiac function in diabetes and prevalence of diabetic complications and the relation to glycaemic control in these patients.

Aims and Objectives-

1. To assess cardiac function in 30 cases of diabetes mellitus.

2. To assess the prevalence of complications.

3. To assess the relation of glycaemic control to complications.

4. Prevalence of other risk factors.

\section{MATERIALS AND METHODS}

Thirty consecutive patients with diabetes of 5 to 10 years duration, attending the diabetic clinic of Govt. Medical College, Kozhikode, Kerala were randomly selected. Detailed history regarding onset and duration of diabetes, symptoms of target organ involvement was taken. Detailed clinical examination and necessary investigations were done.

\section{RESULTS}

1. Retinopathy was present in 43.33\%; 2 . Proteinuria was present in 40\%; 3. Neuropathy was present in 56-66\%; 4. Commonest lipid abnormality was increased HDL followed by low LDL; 5 . LV mass was increased; 6 . Exercise stress test was positive in $30 \%$; 6. Diastolic dysfunction was present in $26.66 \%$; 7. Increase in mean IVS thickness was noted.

\section{CONCLUSION}

1. Diastolic dysfunction is common in diabetes (26.66\% in this study); 2 . Subclinical ischaemic heart disease contributes more to cardiac dysfunction in diabetes than diabetic cardiomyopathy (75\% in this study); 3 . Left ventricular mass is increased in diabetic patients; 4 . Silent ischaemia is common in diabetes (30\% in this study).

\section{KEY WORDS}

Diabetes Mellitus, Diabetic Cardiomyopathy.

HOW TO CITE THIS ARTICLE: Kannath M. Evaluation of cardiac function in diabetes mellitus. J. Evolution Med. Dent. Sci. 2018;7(46):4964-4969, DOI: 10.14260/jemds/2018/1105

\section{BACKGROUND \\ Diabetes mellitus is a syndrome characterised by} abnormalities of carbohydrate, lipid and protein metabolism resulting from either a deficiency of insulin or its metabolic effects. It is manifested as sustained hyperglycaemia and development of microvascular complications like retinopathy, nephropathy and neuropathy and macrovascular complications of accelerated atherosclerosis of coronary and peripheral circulation.

The risk of cardiovascular disease is substantially increased in patients with both type 1 and type 2 diabetes. Cardiovascular risk seems to be particularly high in those people who develop microalbuminuria and proteinuria indicating a common factor involving blood vessel integrity, both in the kidney and elsewhere.

'Financial or Other Competing Interest': None.

Submission 30-09-2018, Peer Review 24-10-2018,

Acceptance 30-10-2018, Published 12-11-2018.

Corresponding Author:

Mridulkumar Kannath,

Shreyas, Mudappattuthazham,

Karuvissery P. O., Kozhikode-673010,

Kerala, India.

E-mail: mridulkumar.k@gmail.com

DOI: $10.14260 / \mathrm{jemds} / 2018 / 1105$

\section{(c) (i) $(9)$}

Macrovascular disease involves arteries and is
indistinguishable from the atheromatous process, which occur in non-diabetic subjects. Microvascular disease affects capillaries, particularly in the retina and glomeruli.

The diabetes is a risk factor for congestive heart failure has been established for decades, but the knowledge of the pathophysiology and treatment of heart failure in diabetes is limited.

Diabetic cardiomyopathy is characterised by congestive heart failure in the absence of valvular, hypertension, atherosclerotic, congenital or alcoholic heart disease. The relation of cardiomyopathy to diabetes is supported by an increased prevalence of unexplained congestive heart failure in diabetes and by autopsy reports of cardiac hypertrophy in the absence of specific cardiac disease. In the Studies of Left Ventricular Dysfunction trials [SOLVD] and registry diabetes was found to be an independent risk factor for mortality and morbidity in both symptomatic and asymptomatic heart failure. Despite similar left ventricular systolic function, patients with diabetes have more pronounced heart failure symptoms, use more diuretics and have an adverse prognosis compared to those without diabetes. One explanation for this discrepancy is diastolic dysfunction of the left ventricle. Type 2 diabetes increases the risk of coronary artery disease by a factor of two to four. Diabetics are more prone for silent ischaemia of the myocardium. 
The relationship between the metabolic control and the development of long-term complications of diabetes remains one of the most contentious issues in medicine. The present study is designed to assess the cardiac function in diabetes and prevalence of diabetic complications and to assess the relation to glycaemic control in these patients.

\section{Aims and Objectives}

1. To assess cardiac function in 30 cases of diabetes mellitus.

2. To assess the prevalence of complications.

3. To assess prevalence of other risk factors and the glycaemic control.

\section{MATERIALS AND METHODS}

\section{Study Design}

Cross-sectional study.

\section{Materials}

Thirty consecutive patients with diabetes of 5 to 10 years duration attending the diabetic clinic of Govt. Medical College Kozhikode, Kerala were randomly selected for this study. Patients with definite evidence of coronary artery disease like angina and/or myocardial infarction, or baseline ECG showing ischaemic changes were excluded from the study.

\section{Methods}

Detailed history was taken from all patients. Systemic examination including autonomic function was assessed. Urine routine, 24-hour urine protein, serum creatinine and lipid profile was done in all patients. Chest x-rays, x-ray of abdomen for pancreatic calculi were taken in selected patients.

\section{All Patients Underwent an Exercise Stress Test (TMT) and Echocardiographic Evaluation}

LV mass was calculated by the formula of Devereux and Reichek

i.e. $\mathrm{LVM}=1.04\left[(\mathrm{LVID}+\mathrm{PWT}+\mathrm{IVST})^{3}-\mathrm{LVID}^{3}-14\right]$ grams

Where - LVID - LV internal dimension in diastole

PWT - Posterior wall thickness

IVST - Interventricular septal thickness

14 - Constant

1.04 - Specific gravity of cardiac muscle.

Exercise stress test was done by treadmill test, Bruce protocol. Positive test was taken as ST segment depression, more than $1 \mathrm{~mm}$ or ST segment elevation more than $2 \mathrm{~mm}$.

\section{A Strongly Positive TMT was taken as-}

1. Duration of symptom - limiting exercise $<6$ METS.

2. Failure to increase systolic blood pressure $\geq 120 \mathrm{mmHg}$ or a sustained decrease $\geq 10 \mathrm{mmHg}$ or below rest levels during progressive exercise.

3. ST segment depression $\geq 2 \mathrm{~mm}$, down sloping ST segment, starting at $<6$ METS involving $\geq 5$ leads: persisting $\geq 5 \mathrm{mts}$ into recovery.

4. Exercise-induced ST segment elevation [aVR excluded].

5. Angina at low exercise workloads.

6. Reproducible sustained (> $30 \mathrm{sec}$ ) or symptomatic ventricular tachycardia.

\section{Chronotropic Incompetence}

Chronotropic incompetence refers to a heart rate increment per stage of exercise, that is less than normal or a peak heat rate below predicted at maximal workloads.

\section{Hypotensive Response}

Indicates fall in blood pressure below the pretest value or any fall compared to previous stage blood pressure.

\section{Hypertensive Response}

Refers to blood pressure greater than $200 / 110 \mathrm{mg}$ at any stage.

\section{Cardiac Autonomic Neuropathy}

A patient was considered to have autonomic neuropathy if two or more of the following findings were present-

1. An increased resting heart rate - This is determined after the patient is supine for 15 minutes. A rate in excess of 100 beats per minute is considered abnormal.

2. Decreased beat to beat heart rate variability - This is determined by the difference between the minimum and maximum heart rate as taken from ECG tracings obtained during periods of inspiration and expiration with the patient breathing six times per minute. A variability of less than 10 beats per minute is considered abnormal.

3. An abnormal Valsalva manoeuvre is determined by having the patient blow into a manometer and maintaining $40 \mathrm{mmHg}$ for 15 seconds. Using ECG tracing one calculates the ratio of the longest R-R interval after the manoeuvre to the shortest $\mathrm{R}-\mathrm{R}$ interval during the manoeuvre. The ratio is abnormal, if it is 1.10 .

4. Abnormal heart rate response to standing - during ECG monitoring the ratio of the R-R interval at the thirtieth beat after standing to the R-R interval after the fifteenth beat is determined. Abnormal if the ratio is 1.00 .

5. An excessive fall in blood pressure with standing. The fall in systolic blood pressure after $1 \mathrm{mt}$ of standing is determined. Abnormal if it is greater than $30 \mathrm{mmHg}$.

All the patients underwent an ophthalmologic examination and assessment of renal function also.

\section{Significant Proteinuria}

Was taken as above 150 mgs in 24 hours.

\section{Glycaemic Control}

The mean fasting and postprandial blood sugar values were calculated for each patient by taking 3 consecutive values at an interval of 1 month.

\section{RESULTS}

1. Age and Sex Distribution

Total number of patients -30

Males - 23

Females -7 


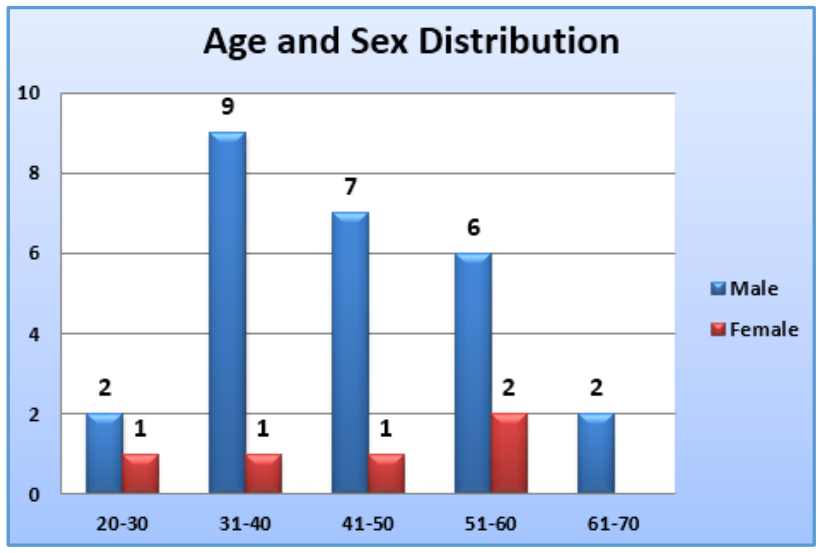

Figure 1

\begin{tabular}{|c|c|c|}
\hline & Mean (Years) & SD \\
\hline Male & 42.47 & 8.55 \\
\hline Female & 48.85 & 14.9 \\
\hline Combined & 43.5 & 10.41 \\
\hline \multicolumn{3}{|c|}{ Table 1 } \\
\hline
\end{tabular}

\section{Comorbid Conditions}

\begin{tabular}{|l|c|c|c|}
\hline \multicolumn{2}{|c|}{ Condition } & No. of Patients & Percentage \\
\hline 1 & Systemic hypertension & 4 & 13.3 \\
\hline 2 & Stroke & 0 & - \\
\hline 3 & Ischaemic heart disease & 0 & - \\
\hline 4 & Smoking & 11 & 36.66 \\
\hline 5 & Pancreatitis & 1 & 3.33 \\
\hline 6 & Tuberculosis & 8 & 26.6 \\
\hline 7 & Family history & 14 & $46.66 \%$ \\
\hline \multicolumn{3}{|c|}{ Table 2 } \\
\hline
\end{tabular}

\begin{tabular}{|c|c|c|}
\hline & Mean & SD \\
\hline 3. Waist/hip ratio & 0.87 & 0.064 \\
\hline 4. Body mass index & 19.76 & 2.45 \\
\hline \multicolumn{3}{|c|}{ Table 3 } \\
\hline
\end{tabular}

\section{Specific Complications of Diabetes Mellitus} 1) Retinopathy

\begin{tabular}{|c|c|c|}
\hline & No. of Patients & Percentage \\
\hline Non-Proliferative & 11 & 36.66 \\
\hline Proliferative & 2 & 6.66 \\
\hline Total & $\mathbf{1 3}$ & $\mathbf{4 3 . 3 3}$ \\
\hline \multicolumn{2}{|c|}{ Table 4 } \\
\hline
\end{tabular}

\section{2) Nephropathy}

\begin{tabular}{|c|c|c|}
\hline & No. of Patients & Percentage \\
\hline Significant proteinuria & 12 & 40 \\
\hline Increased serum creatinine & 4 & 13.33 \\
\hline Nephrotic-range proteinuria & 2 & 6.66 \\
\hline \multicolumn{2}{|c|}{ Table 5 }
\end{tabular}

\section{3) Neuropathy}

\begin{tabular}{|c|c|c|}
\hline & No. of Patients & Percentage \\
\hline $\begin{array}{c}\text { Distal symmetric } \\
\text { polyneuropathy }\end{array}$ & 17 & 56.66 \\
\hline Autonomic neuropathy & 10 & 33.33 \\
\hline Cardiac autonomic neuropathy & 7 & 23.33 \\
\hline \multicolumn{2}{|c|}{ Table 6 } \\
\hline
\end{tabular}

\section{Biochemical Tests}

Lipid Profile

\begin{tabular}{|c|c|c|c|c|c|}
\hline & $\begin{array}{c}\text { Mean } \\
\text { (mg/dL) }\end{array}$ & SD & $\begin{array}{c}\text { Dys } \\
\text { lipidaemia }\end{array}$ & No. & $\begin{array}{c}\text { Per } \\
\text { centage }\end{array}$ \\
\hline Triglycerides & 91.4 & 53.82 & $>200 \mathrm{mg} / \mathrm{dL}$ & 1 & 3.33 \\
\hline $\begin{array}{c}\text { Total } \\
\text { Cholesterol }\end{array}$ & 199.03 & 48.49 & $>240 \mathrm{mg} / \mathrm{dL}$ & 7 & 23.33 \\
\hline HDL & 42.3 & 12.66 & $\leq 35 \mathrm{mg} / \mathrm{dL}$ & 8 & 26.66 \\
\hline LDL & 123 & 12.34 & $\geq 130$ & 9 & 30 \\
\hline VLDL & 17.25 & 10.5 & & & \\
\hline \multicolumn{7}{|c|}{ Table 7 } \\
\hline
\end{tabular}

\section{Evaluation of Cardiac Function}

\section{Clinical Assessment}

No evidence of cardiomegaly or cardiac failure in any patients.

Baseline ECG - normal in all patients.

Echocardiographic Assessment

\begin{tabular}{|c|c|c|c|c|c|}
\hline & & $\begin{array}{c}\text { Patients } \\
\text { (Mean) } \\
\mathrm{cm} \\
\end{array}$ & SD & $\begin{array}{c}\begin{array}{c}\text { Normal(11) } \\
\text { (Mean) } \\
\text { cm }\end{array} \\
\end{array}$ & Range(11) \\
\hline 1. & $\begin{array}{l}\text { Left atrial } \\
\text { dimension }\end{array}$ & 2.87 & 0.3 & 2.9 & $1.9-4$ \\
\hline 2. & IVS thickness & 0.99 & 0.19 & 0.9 & $0.6-1.1$ \\
\hline & $\begin{array}{l}\text { LV. Posterior } \\
\text { wall thickness }\end{array}$ & 0.952 & 0.22 & 0.9 & $0.6-1.1$ \\
\hline 4 & LVIDD & 4.19 & 0.65 & 4.7 & $3.5-5.7$ \\
\hline & $\begin{array}{l}\text { Peak aortic } \\
\text { velocity }\end{array}$ & 1.10 & 0.25 & 1.35 & $1.0-1.7$ \\
\hline 6. & $\begin{array}{l}\text { Ejection } \\
\text { fraction }\end{array}$ & 69.23 & 7.9 & & \\
\hline
\end{tabular}

\begin{tabular}{|c|c|c|}
\hline $\begin{array}{c}\text { Mitral E/A. ratio i.e. peak early/ } \\
\text { peak late. (atrial) filling velocity }\end{array}$ & $1.10 \pm 0.25$ & $\begin{array}{c}(\text { Zarich } \\
\text { et al } 12) \\
1.66 \pm 0.33\end{array}$ \\
\hline $\begin{array}{c}\text { Number of patients with E/A } \\
\text { reversal }\end{array}$ & $8[26.66 \%]$ & \\
\hline $\begin{array}{c}\text { Number of patients with } \\
\text { asymmetrical septal hypertrophy }\end{array}$ & 3 & \\
\hline $\begin{array}{c}\text { Number of patients with } \\
\text { concentric LVH }\end{array}$ & 1 & \\
\hline $\begin{array}{c}\text { Number of patients with regional } \\
\text { wall motion abnormality }\end{array}$ & 0 & \\
\hline $\begin{array}{c}\text { Number of patients with significant } \\
\text { valvular lesions }\end{array}$ & 0 & \\
\hline \multicolumn{2}{|c|}{ Table 9 } \\
\hline
\end{tabular}

\begin{tabular}{|c|c|c|c|c|}
\hline & $\begin{array}{c}\text { Males } \\
\text { (Mean) }\end{array}$ & SD & $\begin{array}{c}\text { Females } \\
\text { (Mean) }\end{array}$ & SD \\
\hline LV mass (gms) & 158.22 & 54.99 & 131.34 & 27.02 \\
\hline $\begin{array}{c}\text { LV mass/Body } \\
\text { surface area gms/m² }\end{array}$ & 103.4 & 48.2 & 91.2 & 28.2 \\
\hline \multicolumn{5}{|c|}{ Table 10 } \\
\hline
\end{tabular}

\section{Left Ventricular Mass}

\begin{tabular}{|c|c|c|c|c|}
\hline & \multicolumn{2}{|c|}{$\begin{array}{c}\text { Hypertensive } \\
\text { Diabetics }\end{array}$} & $\begin{array}{c}\text { Non-Hypertensive } \\
\text { Diabetics }\end{array}$ \\
\hline & Mean & SD & Mean & SD \\
\hline $\begin{array}{c}\text { LV mass } \\
\text { (gms) }\end{array}$ & 132.28 & 19.10 & 154.37 & 54.66 \\
\hline IVSD (cm) & 1.2 & 0.22 & 0.96 & 0.18 \\
\hline E/A ratio & 0.92 & 0.28 & 1.12 & 0.25 \\
\hline \multicolumn{5}{|c|}{ Table 11 } \\
\hline
\end{tabular}




\begin{tabular}{|c|c|c|c|}
\hline \multicolumn{2}{|c|}{$\begin{array}{c}\text { Patients with a positive test, i.e. ST segment } \\
\text { depression > 1 mm or ST elevation greater } \\
\text { than 2 mm }\end{array}$} & 9 & 30 \\
\hline 2 & Patients with as strongly positive test & 2 & 6.66 \\
\hline 3 & $\begin{array}{c}\text { 85\% of above maximum predicted heart } \\
\text { rate attained }\end{array}$ & 25 & 83.33 \\
\hline 4 & Chronotropic incompetence & 0 & 0 \\
\hline 5 & Hypotensive response & 1 & 3.33 \\
\hline 6 & Hypertensive response & 6 & 20 \\
\hline 7 & $<10$ METS of exercise & 4 & 13.33 \\
\hline 8 & $\begin{array}{c}\text { Number of patients developing ventricular } \\
\text { ectopics }\end{array}$ & 2 & \\
\hline 9 & Ventricular arrhythmias & 0 & \\
\hline 10 & Angina & 0 & \\
\hline 11 & LV dysfunction & 0 & \\
\hline \multicolumn{4}{|c|}{ Table 12 } \\
\hline
\end{tabular}

\section{Exercise Stress Test}

Diastolic Dysfunction/ Positive Stress Test

- Diastolic dysfunction - 8

- Diastolic dysfunction + positive stress test $-6 / 8=(75 \%)$

- Positive stress test -9

- Positive stress test + diastolic dysfunction $-5 / 9=(55 \%)$

\section{Nephropathy/ Retinopathy}

- $\quad$ Significant proteinuria -12

- Proteinuria + retinopathy - 10/12 (83\%)

- Retinopathy - 13

- Retinopathy + proteinuria - 10/13 (76.9\%)

Correlation of Proteinuria with Cardiac Function

\begin{tabular}{|c|c|c|c|c|}
\hline & Proteinuria & $\mathbf{\%}$ & $\begin{array}{c}\text { Non- } \\
\text { Proteinuria }\end{array}$ & $\mathbf{\%}$ \\
\hline $\begin{array}{c}\text { Positive stress } \\
\text { test }\end{array}$ & 5 & 55.5 & 4 & 44.44 \\
\hline $\begin{array}{c}\text { Diastolic } \\
\text { dysfunction }\end{array}$ & 4 & 50 & 4 & 50 \\
\hline Combined & 9 & 52.91 & 8 & 47.05 \\
\hline $\begin{array}{c}\text { Mean LV } \\
\text { mass (gm) }\end{array}$ & 135.11 & & 155.21 & \\
\hline $\begin{array}{c}\text { Cardiac autonomic } \\
\text { neuropathy }\end{array}$ & 4 & 50 & 4 & 50 \\
\hline \multicolumn{5}{|c|}{ Table 13 } \\
\hline
\end{tabular}

\section{Correlation of Retinopathy with Cardiac Function}

\begin{tabular}{|c|c|c|c|c|}
\hline & $\begin{array}{c}\text { Retino } \\
\text { pathy }\end{array}$ & $\mathbf{\%}$ & $\begin{array}{c}\text { Non-Retino } \\
\text { pathy }\end{array}$ & $\%$ \\
\hline Positive stress test & 5 & 55.5 & 4 & 44.44 \\
\hline Diastolic dysfunction & 3 & 37.5 & 5 & 62.5 \\
\hline Combined & 8 & 47.05 & 9 & 52.9 \\
\hline Mean LV mass (gm) & 137.64 & & 156.41 & \\
\hline $\begin{array}{c}\text { Cardiac autonomic } \\
\text { neuropathy }\end{array}$ & 4 & 57.1 & 3 & 42.8 \\
\hline \multicolumn{5}{|c|}{ Table 14 } \\
\hline
\end{tabular}

\section{Lipid Abnormalities and Cardiac Function}

\begin{tabular}{|c|c|c|c|c|}
\hline & $\begin{array}{c}\text { Stress } \\
\text { Test +ve }\end{array}$ & $\begin{array}{c}\text { Stress } \\
\text { Test -ve }\end{array}$ & $\begin{array}{c}\text { Diastolic Dys } \\
\text { function +ve }\end{array}$ & $\begin{array}{c}\text { Diastolic Dys } \\
\text { function -ve }\end{array}$ \\
\hline $\begin{array}{c}\text { Mean LDL } \\
\text { levels } \\
\text { mg/dL }\end{array}$ & 119.44 & 124.5 & 127.75 & 116 \\
\hline $\begin{array}{c}\text { Mean HDL } \\
\text { levels } \\
\text { mg/dL }\end{array}$ & 40 & 43.8 & 40.86 & 53.0 \\
\hline \multicolumn{5}{|c|}{ Table 15 } \\
\hline
\end{tabular}

\section{Glycaemic Control}

All the patients were inadequately controlled.

Mean FBS value has $201 \pm 58.9 \mathrm{mg} / \mathrm{dL}$.

PPBS was $252 \pm 70.35 \mathrm{mg} / \mathrm{dL}$.

\section{DISCUSSION}

30 diabetic patients with diabetes of a duration of 5 to 10 years since the detection of illness attending the diabetic clinic of Govt. Medical College, Kozhikode, Kerala were randomly selected for the study. None of the patients had history or evidence of angina and/or myocardial infarction. The baseline ECG was normal.

There were 23 males and 7 females in the study. Mean age of males was 42.47 and that of females was 48.85 years.

The majority i.e. $83 \%$ of the patients presented initially with classical symptoms i.e. polydipsia, polyuria, polyphagia. Although, the blood sugar control was not adequate, none of them gave history suggestive of ketoacidosis or hyperosmolar coma. Symptoms of hypoglycaemia were present in 4 subjects. Systemic hypertension is a common accompaniment of diabetes, especially type 2DM as the disease progresses. In the present study, there were only four hypertensive patients [13.3\%]. This may be due to the shorter duration of illness. All the 4 patients were on antihypertensive drugs.

NIDDM and its metabolic control are important predictors of stroke in elderly subjects.(1) In a 3.5 years follow-up study, Kuusisto J et al showed that NIDDM, its metabolic control and the duration of diabetes are important predictors of stroke in elderly subjects, particularly in women. There were no cases of stroke or TIA in the present study. This may be due to the smaller group of subjects studied or due to younger age of the subjects.

Smoking- Besides increasing the risk of cardiovascular events is an independent risk factor for the development of nephropathy in patients with type 2 diabetes and is associated with an accelerated loss of renal function. Smoking cessation alone may reduce the risk of progression of

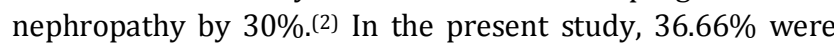
smokers.

Retinopathy was present in 13 patients (43.33\%), proliferative retinopathy was present in two patients. Neuropathy was present in 17 patients [56.66\%]. Autonomic neuropathy was present in 10 patients. Cardiac autonomic neuropathy was present in 7 patients (23.33\%).

The most common lipid abnormality seen in the present study was elevated LDL levels followed by decreased HDL levels. The triglyceride levels were abnormal only in one patient. 
Clinical assessment of the cardiac function was normal. There was no cardiomegaly or evidence of cardiac failure in the subjects.

Diastolic dysfunction is a frequent finding in many studies of cardiac functions in type 2 diabetic subjects without symptoms and signs of heart disease. Most of the studies did not angiographically exclude coronary artery disease.

Diastolic dysfunction independent of ischaemic heart disease is presumably due to diabetic cardiomyopathy.(3) In the present study an exercise stress test was performed to assess pre-clinical coronary artery disease, although angiography was not performed.

The mean left atrial dimension in the study patients was $2.87 \pm 0.3 \mathrm{~cm}$, which was comparable to the mean normal value, i.e. $2.9 \mathrm{~cm}$. An increase in the mean IVS thickness was noted, i.e. $0.99 \pm 0.9 \mathrm{~cm}$ (normal $0.9 \mathrm{~cm})$.

Patients with diabetes and hypertension have thicker interventricular septum when compared to non-diabetic hypertensive patients. (4) Ejection fractions in the study was normal.

Poirier et at ${ }^{(5)}$ studied 46 men with type 2 diabetes who were aged 38 - 46 years without evidence of diabetic complications, hypertension, coronary artery disease, congestive heart failure or thyroid or overt renal disease and with a maximal treadmill exercise test showing no ischaemia. LV diastolic dysfunctions were evaluated by Doppler echocardiography, which included the use of Valsalva manoeuvre and pulmonary venous recordings to unmask a pseudonormal pattern of left ventricular filling. LV diastolic dysfunction was found in 28 subjects (60\%), of whom 13 (28\%) had a pseudonormal pattern of ventricular filling and $15(32 \%)$ had impaired relaxation. Systolic function was normal in all subjects and there was no correlation between LV diastolic dysfunction and indexes of metabolic control.

Zarich SW and Aurbuckle BE et al(6) studied indexes of left ventricular diastolic filling by pulsed Doppler echocardiography in 21 insulin dependent diabetic patients and 21 control subjects without clinical evidence of heart diseases. All patients had a normal ejection fraction. Six (29\%) of the 21 diabetic patients had evidence of diastolic dysfunction.

Hirai J et al(7) studied the effects of metabolic control on ventricular function in type 2 diabetic patients. They found that both systolic and diastolic ventricular dysfunction were improved by the correction of the hyperglycaemia.

Robillon JF et al( ${ }^{(8)}$ assessed the ventricular function is asymptomatic patients with type 1 and type $2 \mathrm{DM}$. The study showed abnormalities suggestive of cardiomyopathy in type 2 diabetic patients with a relatively short duration of known disease, while these alterations were less prominent in type 1 patients despite a long duration of the disease.

Raev DC(9) studied 157 cardiac asymptomatic type 1 diabetic patients. Findings indicated that myocardial damage in patients with diabetes affects diastolic function before systolic function.

Diastolic dysfunction was assessed by mitral E/A ratio, i.e. the ratio of peak early filling to the peak late filling velocity. The value was $1.1 \pm 0.25$. Number of patients with asymmetric septal hypertrophy was 3 . One of them was hypertensive. Both diabetes and hypertension predispose to asymmetric septal hypertrophy. In the remaining 2 patients, diabetes probably contributed to the asymmetric septal hypertrophy.
No patient had regional wall motion abnormality, which excluded prior myocardial infarction. There was also no significant valvular lesions.

Left ventricular mass was calculated by the formula of Devereux and Reichek. Echocardiographic studies have shown increased LV mass in patients with hypertension and diabetes.(10) LV mass in hypertensive diabetics was $132.28 \pm 19.10$ when compared to normotensives (154.37士54.66).

The IVSD was greater in the hypertensive diabetics $(1.2 \pm 0.22$ vs $0.96 \pm 0.18)$ and the E/A ratio was lesser in the hypertensive group $(0.92 \pm 0.28$ vs $1.12 \pm 0.25)$. Thus hypertension had an adverse effect, except on the LV mass. This may be due to the small proportion of the hypertensive patients in the study.

Exercise stress test was positive in 9 patients, 2 of them showing a strongly positive test. None of the patients had angina or LV dysfunction. Chronotropic incompetence was not present in any patients. One patient had a hypotensive response, i.e. fall in the blood pressure when compared to the previous stage of exercise. This patient had a strongly positive test, i.e. ST segment depression in multiple leads. 6 patients had a hypertensive response, of these 3 were known hypertensives. The hypertensive response in the remaining three patients may indicate that they are likely to develop hypertension in the future. $75 \%$ of the patients who had dysfunction had a positive stress test. This indicates that coronary artery disease contributes a major proportion to the cardiac dysfunction in diabetes when compared to cardiomyopathy.

$83 \%$ of the patients with nephropathy had retinopathy. Nephropathy is an important risk factor for cardiac disease in diabetics. In the present study, 55\% of nephropathy patients had silent ischaemia as evidenced by positive TMT. Diastolic dysfunction was present in $50 \%$ of the nephropathy patients. The mean LV mass did not show a positive correlation with nephropathy. $55.5 \%$ of the retinopathy patients had silent ischaemia, whereas diastolic dysfunction was present only in $37.5 \%$. The mean LV mass also did not show a positive correlation with retinopathy.

\section{Glycaemic Control}

The long-term complication of diabetes, i.e. retinopathy, nephropathy and neuropathy can be significantly reduced (Primary prevention) and progression of pre-existing complications can be slowed (Secondary prevention) by good glycaemic control. In the present study, none of the patients had an adequately controlled blood sugar levels.

\section{Limitations of the Present Study}

1. There were no age-matched controls in the study. The controls were taken from similar studies.

2. Angiography was not done to confirm the findings of the exercise stress test.

\section{CONCLUSION}

1. Diastolic dysfunction is common in diabetic patients (26.66\%).

2. Systolic function is normal in diabetes of short duration.

3. Subclinical ischaemic heart disease contributes more to the cardiac dysfunction in diabetes than diabetic cardiomyopathy (75\% in this study). 
4. Coexisting hypertension contributes to the cardiac abnormalities, especially diastolic dysfunction and asymmetric septal hypertrophy.

5. LV mass is increased in diabetic patients.

6. Silent ischaemia is common in diabetics (30\%).

7. Nephropathy is strongly associated with retinopathy (83\%).

8. The commonest lipid abnormality seen in this study was increased, LDL followed by low HDL.

\section{REFERENCES}

[1] Kuusisto J, Mykkanen L, Pyorala K, et al. Non-insulindependent diabetes and its metabolic control are important predictors of stroke in elderly subjects. Stroke 1994;25(6):1157-64.

[2] Remuzzi G, Schieppati A, Ruggenenti P. Clinical practice. Nephropathy in patients with type 2 diabetes. N Eng J Med 2002;346(15):1145-51.

[3] Hardin NJ. The myocardial and vascular pathology of diabetic cardiomyopathy. Coronary Artery Disease 1996;7(2):99-108.

[4] Venco A, Grandi A, Barzizza F, et al. Echocardiographic features of diabetic heart muscle disease. Cardiology 1987;74:28-34.
[5] Poirier P, Bogaty P, Garneau C, et al. Diastolic dysfunction in normotensive men with well controlled type 2 diabetes: importance of maneuvers in echocardiographic screening for preclinical diabetic cardiomyopathy. Diabetes Care 2001;24(1):5-10.

[6] Zarich SW, Nesto RW. Diabetic cardiomyopathy. Am Heart J 1989;118(5 Pt 1):1000-12.

[7] Hirai J, Ueda K, Takegoshi T, et al. Effect of metabolic control on ventricular function in type 2 diabetes mellitus. Intern Med 1992;31(6):725-30.

[8] Robillon JF, Sadoul JL, Jullien D, et al. Abnormalities suggestive of cardiomyopathy in patients with type 2 diabetes of relatively short duration. Diabetes Metab 1994;20(5):473-80.

[9] Raev DC. Which left ventricular function is impaired earlier in the evolution of diabetic cardiomyopathy? An echocardiographic study of young type 1 diabetic patients. Diabetes Care 1994;17(7):633-99.

[10] Grossman E, Shemesh J, Shamiss A, et al. Left ventricular mass in diabetes and hypertension. Arch Intern Med 1992;152(5):1001-4. 